in turn; and finally, Part 3 "constitutes an attempt to analyse the concept of wool improvement and an examination of methods of development of its production".

\section{Academy of Natural Sciences of Philadelphia}

IN an attractive Year Book for 1931, it is recorded that the 120th year of the Academy's existence was signalised by notable activities in many directions. In each of the three major fields-laboratory studies, expeditions, and museum exhibits-the year set new records for this oldest institution of its kind in America. During the year, twenty-two expeditions for organised collecting, sponsored wholly or in part by the Academy, obtained material for study or exhibits from North, South, and Central America, as well as from Asia and Africa, and covered more than 175,000 miles during their quests. One result is seen in the addition of more than 8700 new specimens of vertebrates alone to the study collections. That the museum side of the Academy's activities arouses growing interest is indicated by the increased number of visitors, which for the first time exceeded 100,000; but the photographs of the cases of small mammals in the North American hall give an impression of the grouping of incongruous species, which suggests that here there is still room for the development of artistic natural groups. It is announced in Science that the following have recently been elected correspondents of the Academy : Prof. L. H. Bailey, Dr. H. B. Bigelow, Prof. R. A. Daly, Dr. Ludwig Diels, Prof. J. Stanley Gardiner, Prof. Hugo Glück, Prof. W. D. Gregory, Prof. A. S. Hitchcock, A. Lutz, Prof. E. de Margerie, Prof. E. D. Merrill, E. W. Nelson, Prof. A. C. Seward, Dr. E. O. Ulrich, and Mr. B. P. Uvarov.

\section{Eradication of Slugs and Snails}

SluGs and snails are some of the most widespread pests on farms and in gardens, but owing to their nocturnal habits and their capacity for excreting slime which enables them to get rid of irritating substances, they are very difficult to control. Their natural enemies, for example, various birds, toads, moles, and predaceous ground beetles, are insufficient to keep their numbers in check, and special means of control are often necessary. Though no means of absolute eradication of these pests is as yet known, the Ministry of Agriculture has published an Advisory Leaflet (No. 115), in which various check measures are described. In gardens, large numbers of slugs may be caught by means of traps consisting of cut potatoes, orange skins, cabbage leaves, tiles, boards, or sacking placed on the soil, for the animals will collect under them far shelter during the day. Hand collecting at dusk is also recommended. For larger areas, the use of certain chemicals with a corrosive or toxic action is advised. Quicklime or salt are destructive if they come in contact with the upper part of the slugs' bodies, and applications made at night (or two or three times during the same night, if possible) should prove useful. Barriers of repellent material such as soot, washing soda, 'dry Bordeaux ', etc., are often successful, and recent trials have shown that 1 part creosote mixed with 100 parts of precipitated chalk placed around each plant at the rate of $\frac{1}{4} \mathrm{oz}$. per plant is worth further trial.

\section{Forest Fires}

Leaflet No. 9 issued by the Forestry Commission (H.M.S.O., 1931) deals with this subject, which is of growing importance in Great Britain. The type of forests most subject is the coniferous ; outside tropical regions, fires in forests of broad-leaved trees are less dangerous. Woodland fires are not new in Great Britain, and in dry seasons they have been only too prevalent on commons. The Forestry Commission attributes twenty-five per cent of the fires occurring nowadays in its new forests to carelessness on the part of picnickers and wayfarers. Since the advent of the Forestry Commission and the large coniferous planting campaign which has been inaugurated under its auspices during the past twelve years, the forest fire problem has entered upon a new phase. The most common form of danger is the surface or ground fire, burning dead leaves, etc., on the forest floor. The stem and crown fire is rarer in Great Britain. Newly planted areas are in greatest danger during March and April, although a dry February produces the same conditions. During a summer drought the danger reappears. The grass, under the influence of dry east winds or a summer drought, becomes as dry as tinder, and a cast-away lighted match or burning cigarette-end will start a fire which will quickly get out of control of the perpetrator of the act. After pointing out the various dangers to plantations situated under differing conditions, the leaflet deals with various methods of control, such as lay-out of plantations, order of felling, removal of debris, patrolling, equipment of tool depots, clearance of growth outside plantations, importance of immediate action, counterfiring, and the measures to be taken after the outbreak.

\section{The Making of Factories}

IN Helios for March 20, the export journal of the Zeitschrift für die Elektrotechnik, there is an interesting account of the Gladitz Company of Berlin, the main business of which is to instal and equip completely in every detail lamp-making factories. Any one willing to start a factory for electric lamps need have no technical knowledge of the subject. For example, a capitalist in Mexico City recently ordered a modern lamp-making factory. The plans for the building were prepared by the company and it was erected under the supervision of a local architect. During this time the necessary equipment, down to the smallest detail, was made in Germany. German engineers then went to Mexico and installed the machinery. They took with them a staff of male and female workers. The Mexican labourers, both men and women, were instructed by this staff. In a year's time the instructors had all left, the only German remaining being the technical manager. Three months after the building was erected, lamps began to be manufactured, and the production is now 16,000 per day. The contract comprises the supply of all machines and accessories, the factory organisa-

No. 3272, VoL. 130] 
tion, the instruction of local labour, continuous control, and consultation. The Gladitz Company has already installed complete factories in many countries of the world, with departments for wire treating, glass treating, exhausting, and finishing the lamps. It is interesting to notice that several of these factories are now being controlled by the large lamp companies. The company considers that this is a com. pliment to the work turned out by the factories it has started. It is busy at present in developing practical manufacturing methods of making neon signs for manufacturing purposes.

\section{Precautions in Use of Electro-Medical Apparatus}

Serious accidents from the use of electro-medical apparatus have so far been few in number, but the risk is likely to increase in the future, owing to more extended use of such appliances and also to the tendency to make use of the standard alternating current of 230 volts. Industrial experience shows that serious shock is more likely to result from alternating than from direct currents of the same voltage. The Ministry of Health has therefore issued a Memorandum (Mem. 161 Med.) with covering Circular (No. 1267) directing attention to precautions that ought to be taken in the use of electro-medical appliances, adoption of which should go far to minimise the risks involved.

\section{Researches from the University of Sydney}

The published work of members of the University of Sydney is made more generally available by the issue of collected reprints, which are now classified in twelve series, according to the nature of the research. We have recently received vol. 1, Reprints Nos. 18-24, in Series I. (Agricultural and Veterinary Science), vol. 1, Reprints Nos. 22-32, in Series VIII. (Medical Sciences-Clinical), and vol. 3, Reprints Nos. 1-19, in Series IX. (Medical Sciences-Non-Clinical). Most of the papers have been published within the last two years; a few are of less recent date. Most, but not all, were originally published in Australian journals. The range of subjects dealt with in each volume is wide, and indicates that an active spirit of research animates Australian scientific workers.

\section{Hawaiian Volcano Observatory}

WE regret to learn that, from July 1, the annual fund allotted to volcanology through the U.S. Geological Survey has been reduced from 35,000 to 15,000 dollars. Most of this sum is required for the work of the Hawaiian Volcano Observatory, and one of the first results of the reduction is that the weekly Volcano Letter, first issued in 1925 , is to be replaced by a monthly leaflet. There will be no suspension of the research work, though the staffs at all the stations, n Hawaii, California, and Alaska, will be reduced.

\section{Announcements}

THE fifteenth Faraday Lecture of the Chemical Society will be delivered by Prof. P. Debye, of Leipzig, on March 29, 1933.

DR. H. R. MmI, who during his long association with the Royal Geographical Society has been actively engaged in the promotion and preparation of the polar expeditions of the past forty years or so, has been appointed by the King of Norway a Commander (2nd Class) of the Order of St. Olav, for his services to Norwegian arctic explorers. This order has previously beon conferred upon Sir Clements Markham, Sir Errnest Shackleton, and Sir John Seott Keltie.

Mrs. Bowen, Titcomb Manor, Kintbury, Berks, informs us that she has fifteen bound volumes of Nature, namely, vol. 45 to vol. 60 , extending from Nov. 1891 to Oct. 1899, with the exception of vol. 54, which she generously offers to present to a suitable college, institute, or scientific worker, in need of them, upon payment of carriage. Communications should be sent direct to Mrs. Bowen at the above address.

A special volume (vol. 9) of the Australian Journal of Experimental Biology and Medical Science has been issued as a memento of the late Prof. Brailsford Robertson, who founded the Journal and, until his death in January 1930, was its chief editor. The volume contains a biographical account of his scientific work, a bibliography of his writings, and nineteen papers specially contributed by his former colleagues and pupils, who are all acknowledged authorities on the subjects on which they write. The volume forms a unique and interesting collection of papers on those biochemical aspects of biological science to which the late Prof. Robertson during his lifetime made such notable contributions, both directly by his own individual work and indirectly by his inspiring influence on a wide circle of colleagues and pupils.

THE annual Report of the Governing Body of the Lister Institute of Preventive Medicine, recently issued, announces that Prof. William Bulloch has been elected chairman of the governing body, in succession to the late Sir David Bruce. An excellent survey of the numerous researches carried out by workers at the Institute is presented. The National Collection of Type Cultures, housed at the Institute, has had two hundred cultures added, and has distributed more than five thousand cultures, during the year.

AppricATrons are invited for the following appointments, on or before the dates mentioned:-An assistant lecturer in zoology at the University of Birmingham-The Secretary (July 17). A lecturer in electrical engineering and physics at the Borough Polytechnic, Borough Road, London, S.E.1-The Principal (July 18). A principal of the College, and a headmaster of the College Secondary School, Swindon-The Director of Education, Education Office, Clarence Street, Swindon (July 21). A principal of the new Technical School, Hong-Kong-The Secretary (SIR/CA), Board of Education, Whitehall, London, S.W.1, or, for Scottish applicants, The Secretary, Scottish Education Department, Whitehall, London, S.W.1 (July 23). A lecturer in zoology at University College, Nottingham-The Registrar (July 30). A demonstrator in biology at Guy's Hospital Medical School, London Bridge, S.E.l-The Dean (Aug. 5).

No. 3272 , VoL. 130] 